\title{
PENGARUH PENDEKATAN SAINTIFIK BERBASIS PENILAIAN KINERJA TERHADAP PENGUASAAN KOMPETENSI PENGETAHUAN IPS DITINJAU DARI KEMAMPUAN BERPIKIR KREATIF
}

\author{
Ayu Wulandari ${ }^{1}$, I Wyn.Sujana ${ }^{2}$, I Kt. Ardana ${ }^{3}$ \\ ${ }^{1,2,3}$ Jurusan Pendidikan Guru Sekolah Dasar, FIP \\ Universitas Pendidikan Ganesha \\ Singaraja, Indonesia \\ e-mail : ayuwulandarigeg@gmail.com ${ }^{1}$,sujanawyn59@gmail.com² ${ }^{2}$, \\ ketut ardana55@yahoo.com @undiksha.ac.id ${ }^{3}$
}

\begin{abstract}
Abstrak
Penelitian ini bertujuan untuk (1) Untuk mengetahui perbedaan yang signifikan penguasaan kompetensi kognitif IPS antara siswa yang mengikuti pembelajaran dengan pendekatan saintifik berbasis penilaian kinerja dan pelaksanakan pembelajaran dengan pendekatan saintifik, (2) mengetahui perbedaan yang signifikan penguasaan kompetensi kognitif IPS antara siswa yang mempunyai kemampuan berpikir kreatif tinggi dan kemampuan berpikir kreatif rendah, (3) mengetahui interaksi pelaksanaan pembelajaran dengan pelaksanaan saintifik berbasis penilaian kinerja dan kemampuan berpikir kreatif terhadap penguasaan kompetensi kognitif IPS. Rancangan penelitian ini adalah Nonequivalent Control Group Design, dengan menggunakan desain faktorial 2x2 Anava Dua Jalur. Populasi dalam penelitian ini seluruh siswa kelas V SDN Ir. Soekarno Denpasar Selatan tahun pelajaran 2015/2016. Data yang dikumpulkan adalah data kemampuan berpikir kreatif dan kompetensi kognitif IPS. Hasil penelitian menunjukkan (1) terdapat perbedaan yang signifikan hasil belajar IPS antara siswa yang dibelajarkan melalui pendekatan saintifik berbasis penilaian kinerja dengan kelompok siswa yang dibelajarkan melalui pendekatan saintifik konvensional $\left(F_{\text {Anitung }}=4,94>F_{\text {tabel }(\alpha=0,05 ; 1,82)}=3,98\right)$, (2) tidak terdapat perbedaan yang signifikan antara penguasaan kompetensi kognitif IPS dengan kemampuan berpikir kreatif tinggi dan kemampuan berpikir kreatif rendah $\left.F a_{A B h i t u n g}=12,28>F_{\text {tabel }(\alpha=0,05 ; 1,82)}=3,98\right)$.

Kata kunci : Penilaian Kinerja, Berpikir Kreatif, Kompetensi Kognitif IPS
\end{abstract}

\begin{abstract}
This study aims to (1) to know the significant difference of cognitive competence control of IPS among students who follow the learning with scientific approach based on performance appraisal and implementation of learning with scientific approach, (2) to know the significant difference of mastery of IPS cognitive competence among students who have ability high creative thinking and low creative thinking ability, (3) to know the interaction of learning implementation with scientific implementation based on performance appraisal and creative thinking ability to master IPS cognitive competence. The design of this research is Nonequivalent Control Group Design, using factorial design 2x2 Anava Dua Lane. Population in this study all students of class V SDN Ir. Soekarno Denpasar Selatan academic year 2015/2016. The data collected are data of creative thinking ability and IPS cognitive competence. The results of the study showed that (1) there was a significant difference of IPS learning outcomes between students who were educated through a scientific approach based on performance appraisal with groups of students who were taught by conventional scientific approach $\left.F_{\text {Ahitung }}=4,94>F_{\text {tabel }(\alpha=0,05 ; 1,82)}=3,98\right)$, (2) there is no significant difference between mastery competence cognitive social class to the ability of creative thinking high and the capacity to think creative low students and the $\left(F_{B}=0,97>F_{\text {tabel }(\alpha=0,05 ; 1,82))}=3,98\right)$, (3) there are the influence of an interaction between rendering based approach performance assessment and creative thinking learning of the results of the social class $\left(F_{\text {ABnitung }}=12,28>F_{\text {tabel }(\alpha=0,05 ; 1,82)}=3,98\right)$.
\end{abstract}

Keywords: Performance Appraisal, Creative Thinking, IPS Cognitive Competence 
Journal for Lesson and Learning Studies Vol. 1 No. 3, 2018

P-ISSN : 2615-6148, E-ISSN : 2615-7330

\section{Pendahuluan}

Pendidikan di sekolah dasar bertujuan untuk menanamkan dasar - dasar kecakapan baik dari segi pengetahuan, sikap dan keterampilan yang akan diterapkan siswa dalam kehidupan sehari -harinya. Proses pembelajaran sangat bergantung dari 2 peran ini, yakni guru dan siswa. Guru dalam proses belajar mengajar tidak hanya mengajarkan mengenai pelajaran saja namun juga sebagai fasilitator bagi siswanya Pendidikan di sekolah dasar guru akan mengajarkan berbagai mata pelajaran dan salah satunya adalah IImu Pengetahuan Sosial (IPS). IImu pengetahuan social adalah suatu program pendidikan yang mempersoalkan manusia dalam lingkungan alam fisik, maupun lingkungan sosialnya. Tujuan pendidikan IPS tidak hanya sekedar membekali siswa dengan berbagai informasi yang bersifat hafalan (kognitif) saja, akan tetapi IPS harus mampu mengembangkan keterampilan berpikir, agar siswa mampu mengkaji berbagai kenyataan sosial beserta permasalahannya (Susanto 2014: 145). Dalam pendidikan di sekolah dasar diperlukannya strategi pembelajaran yang tepat demi optimalnya proses pembelajaran. Dalam proses pembelajaran strategi pembelajaran yang efektif, efisien dan menyenangkan sangat diperlukan demi tercapainya tujuan pembelajaran yang diharapkan. Dengan strategi pembelajaran yang tepat siswa akan dimotivasi untuk belajar memecahkan suatu masalah yang dihadapinya. Sehingga siswa akan mengembangkan kemampuan berpikir kreatif dan menemukan serta mengemukakan ide - ide baru untuk menjawab permasalahan maupun pertanyaan yang dihadapi oleh siswa. Menurut Badan Standar Nasional Pendidikan (2011:16) mengemukakan "Ilmu Pengetahuan Sosial (IPS) merupakan salah satu mata pelajaran yang diberikan mulai dari SD/MI/SDLB sampai SMP/MTs/SMPLB". IPS mengkaji seperangkat, peristiwa, fakta, konsep dan generalisasi yang berkaitan dengan isu sosial. Pada jenjang SD/MI mata pelajaran IPS memuat materi Geografi, Sejarah, Sosiologi, Antropologi, Tata Negara dan Ekonomi. Melalui mata pelajaran IPS peserta didik diarahkan untuk dapat menjadi warga Negara Indonesia yang demokratis dan bertanggung jawab, serta warga dunia yang cinta damai.

Muatan materi IPS dalam pembelajaran di sekolah dasar tidak hanya memberikan ilmu pengetahuan semata, tetapi juga berorientasi pada pengembangan keterampilan sikap. Menurut Permendikbud 104 tahun 2014 kompetensi pengetahuan dinyatakan dalam skor tertentu untuk kemampuan berfikir dan dimensi pengetahuannya, kompetensi pengetahuan berkaitan dengan hasil belajar kemampuan kognitif siswa. Kompetensi kognitif adalah pengunaan pengetahuan, berkembangnya fungsi intelektual atau proses perkembangan kecerdasan. Hal ini sejalan dengan yang diungkapkan oleh syah (2011: 59) perkembangan kognitif (cognitive development) yakni proses perkembangan fungsi intelektual atau proses perkembangan kemampuan/kecerdasan anak. Gunawan (2011:39) menyebutkan ruang lingkup IPS SD meliputi aspek-aspek sebagai berikut. 1) manusia, tempat, dan lingkungan; 2) waktu, keberlanjutan, dan perubahan; 3) sistem sosial dan budaya; 4) perilaku ekonomi dan kesejahteraan; 5) IPS SD sebagai pendidikan global (global education), yakni mendidik siswa akan kebhinekaan bangsa, budaya, dan peradaban di dunia, menanamkan kesadaran semakin terbukanya komunikasi dan transportasi antar bangsa di dunia, mengurangi kemiskinan, kebodohan, dan perusakan lingkungan. Dalam hal tersebut kompetensi atau hasil belajar juga merupakan hasil dari aktivitas proses. Karena ruang lingkup IPS di SD sangatlah luas dan untuk memperoleh kompetensi pengetahuan IPS melalui pendidikan IPS di sekolah, siswa diharapkan memiliki pengetahuan dan wawasan tentang konsep dasar ilmu sosial dan humaniora, memiliki kepekaan dan kesadaran terhadap masalah sosial dilingkungannya, dan mampu memecahkan masalah sosial secara baik. Upaya memperbaiki kompetensi siswa yang mencakup pengetahuan, keterampilan, serta sikap dan perilaku merupakan angin segar yang diharapkan dapat diterapkan secara benar untuk menghasilkan insan cerdas yang beriman sesuai dengan 
Journal for Lesson and Learning Studies Vol. 1 No. 3, 2018

P-ISSN : 2615-6148, E-ISSN : 2615-7330

tujuan pendidikan nasional, maka guru diharapkan mampu membimbing siswa untuk menemukan pengetahuannya dengan mengembangkan pembelajaran yang inovatif.

Pendekatan saintifik adalah pendekatan pada pembelajaran yang berpusat pada siswa yang bersifat ilmiah dan menekankan aktivitas siswa aktif dengan melakukan temuan yang bermakna sehingga siswa mampu mengkonstruk konsep pembelajarannya sendiri melalui kegiatan mengamati, menanya, mengumpulkan informasi, mengasosiasikan dan mengkomunikasikan. Penilaian kinerja dapat disimpulkan bahwa penilaian yang mengukur perilaku dan pengetahuan siswa dari kegiatan yang dirancang oleh guru dalam proses pembelajaran dimana penilaian ini bisa diukur berdasarkan kriteria tertentu. Menurut Bochenski (Hawadi 2010:84) berpikir adalah perkembangan ide dan konsep. Jadi dapat disimpulkan bahwa berpikir adalah proses berkembangnya ide dan konsep yang menghasilkan pengetahuan. Kreativitas adalah kemampuan untuk mengungkapkan hubungan - hubungan baru, melihat sesuatu dari sudut pandang baru untuk membentuk kombinasi baru dari dua konsep atau lebih yang dikuasai sebelumnya. Berdasarkan hasil observasi dan wawancara yang dilakukan di SD Gugus Ir. Soekarno dengan guru wali kelas V Denpasar, dikatakan bahwa pelaksanaan proses pembelajaran sudah berjalan baik, khususnya untuk pembelajaran IPS. Dalam pelaksanaannya guru melaksanakan pembelajaran dengan cara ceramah, tanya jawab, diskusi, dan pemberian tugas. Pembelajaran di kelas guru lebih aktif sedangkan siswa menjadi pasif di kelas. Dengan demikian suasana pembelajaran menjadi tidak kondusif. Hal tersebut membuat pembelajaran di kelas menjadi tidak optimal.Sesuai dengan kurikulum 2013 yang kini tengah diterapkan di sekolah dasar. Keberhasilan program pembelajaran dilihat dari ketuntasan siswa dalam menyerap seluruh materi yang ada dalam kurikulum. Namun masih saja bagi guru keberhasilan program pembelajaran dilihat dari penyampaian materi saja. Sehingga hasil belajar dan kemampuan kognitif siswa yang diperoleh siswa masih kurang optimal. Untuk mengoptimalkan pembelajaran di kelas dapat menggunakan pendekatan saintifik berbasis penilaian kinerja yang membantu mengaktifkan siswa dalam proses pembelajaran. Pendekatan saintifik adalah pendekatan yang dalam kegiatan pembelajarannyaberpusat pada siswa dan siswa diajak untuk mencari tahu dan mencoba serta berpikir ilmiah. Sedangkan penilaian kinerja adalah penilaian yang mengukur perilaku dan pengetahuan siswa dari kegiatan yang dirancang oleh guru dalam proses pembelajaran yang diukur berdasarkan kriteria tertentu. Jadi pendekatan saintifik berbasis penilaian kinerja adalah pendekatan yang berpusat pada siswa dan siswa diajak untuk mencari tahu dan mencoba serta berpikir ilmiah dimana nantinya proses pembelajaran ini akan menilai pengetahuan dan psikomotor siswa berdasarkan kriteria tertentu. Berpijak dari latar belakang di atas, maka akan dikaji lebih luas permasalahannya, yaitu dengan penelitian yang berjudul: "Pengaruh Pendekatan Saintifik Berbasis Penilaian Kinerja terhadap Penguasaan Kompetensi Kognitif IPS Siswa SD Kelas V Ditinjau dari Kemampuan Berpikir Kreatif Gugus Ir. Soekarno Kecamatan Denpasar Selatan".

Tujuan yang ingin dicapai dalam penelitian ini adalah untuk : (1) Mengetahui perbedaan yang signifikan penguasaan kompetensi kognitif IPS antara siswa yang mengikuti pembelajaran dengan pendekatan saintifik berbasis penilaian kinerja dan pelaksanakan pembelajaran dengan pendekatan saintifik pada siswa kelas V SD Gugus Ir. Soekarno Kecamatan Denpasar Selatan. (2) Mengetahui perbedaan yang signifikan penguasaan kompetensi kognitif IPS antara siswa yang mempunyai kemampuan berpikir kreatif tinggi dan kemampuan berpikir kreatif rendah pada siswa kelas V SD Gugus Ir. Soekarno Kecamatan Denpasar Selatan. (3) Mengetahui interaksi pelaksanaan pembelajaran dengan pelaksanaan saintifik berbasis penilaian kinerja dan kemampuan berpikir kreatif terhadap penguasaan kompetensi kognitif IPS pada siswa kelas V SD Gugus Ir.Soekarno Kecamatan Denpasar Selatan.

Dilihat dari hasil penelitian yang dilakukan oleh (1) Yantiani (2013) menunjukkan terdapat perbedaan yang signifikan hasil belajar siswa yang mengikuti model pembelajaran kooperatif 
Journal for Lesson and Learning Studies Vol. 1 No. 3, 2018

P-ISSN : 2615-6148, E-ISSN : 2615-7330

tipe pair check Berbasis Penilaian Kinerja dengan siswa yang mengikuti pembelajaran konvensional; (2) Penelitian yang dilakukan oleh Widiadnyani (2014) menunjukkan terdapat perbedaan yang signifikan terhadap hasil belajar PKN antara siswa yang dibelajarkan dengan model pembelajaran Pair Cheks Berbasis Penilaian Kinerja berbatuan media lingkungan hidup dengan siswa yang dibelajarkan dengan pembelajaran konvensional. Berdasarkan pemaparan tersebut, maka dilakukan penelitian yang berjudul Pengaruh Model Pembelajaran Pair Check Berbasis Penilaian Kinerja Terhadap Kompetensi Pengetahuan PKn Siswa Kelas IV SDN Gugus Pattimura Denpasar Selatan Tahun Pelajaran 2017/2018. suwarni hasibuan, hera deswita. (2017) Berdasarkan hasil penelitian yang dilakukan di SMP N 2 tambusai, diperoleh hitungan rata-rata kemampuan hasil belajar matematis siswa kelas VIII2 (Kelas eksperimen) dengan penerapan model pembelajaran Pair Check Berbasis Penilaian Kinerja dari 69,50 meningkat menjadi 84,20 dan rata-rata kemampuan hasil belajar. Model pembelajaran Pair Check memberikan hasil yang lebih baik dibandingkan dengan pembelajaran konvensional. Hal itu terjadi karena Pair Check melibatkan peserta didik dalam proses pembelajaran aktif dan kolaboratif, serta berpusat kepada peserta didik, sehingga mampu mengembangkan hasil belajar secara mandiri. Edy Setiyo Utomo (2016). Berdasarkan analisa data, peneliti menyimpulkan bahwa model cooperatif learning tipe pair check Berbasis Penilaian Kinerja efektif dalam pembelajaran materi pokok peluang pada siswa kelas XI di MAN Tambakberas Jombang. Simpulan tersebut didasarkan pada hal sebagai berikut: Nilai rata-rata siswa kelas eksperimen sebesar 83,63 dan nilai rata-rata siswa kelas kontrol sebesar 61,32. Nilai t hitung sebesar $-12,822$. Hal ini berarti hasil belajar matematika siswa kelas eksperimen lebih baik daripada hasil belajar matematika siswa kelas kontrol. Sedangkan untuk taraf signifikasi $5 \%$, harga t0,975 dengan $\mathrm{dk}=76$ dari daftar distribusi $\mathrm{t}$ adalah 2,00. Hal ini berarti harga t hitung tidak terletak antara $-2,00$ dan 2,00 serta probabilitasnya $<0,05$ yaitu 0,000 $<0,05$. Putri Ayu Widiadnyani (2014). Hasil penelitian dan pembahasan dapat disimpulkan bahwa terdapat pengaruh yang signifikan terhadap hasil belajar IPA antara siswa yang dibelajarkan dengan model pembelajaran Pair- Cheks Berbasis Penilaian Kinerja berbatuan media lingkungan hidup dengan siswa yang dibelajarkan dengan pembelajaran konvensional. Ini terbukti dari hasil analisis dengan uji- $t$ diperoleh thitung sebesar 2,20 sedangkan ttabel sebesar 1,99 pada taraf signifikan $5 \%$ dan $\mathrm{dk}=83(\mathrm{n} 1+\mathrm{n} 2-2=43+42-2=83)$. Nilai ratarata siswa kelompok eksperimen sebesar 83,56 lebih besar dari rata- rata kelas kelompok kontrol yaitu 78,91. Ini berarti bahwa model pembelajaran Pair- Cheks berbantuan media lingkungan hidup berpengaruh terhadap hasil belajar IPA siswa kelas V SDN 5 Pedungan tahun ajaran 2013/ 2014. Admiyetti, Syamwil (2016) Berdasarkan hipotesis dua, hasil pengolahan data melalui Anova diperoleh bahwa minat belajar sangat berperan terhadap Perolehan hasil belajar akuntansi siswa kelas X AK di SMKN 1 Lubuk Basung. Dari hasil pengujian hipotesis dapat dilihat bahwa terdapat perbedaan hasil belajar antara siswa yang memiliki minat belajar tinggi dengan siswa siswa yang memiliki minat belajar rendah baik di kelas eksperimen maupun di kelas kontrol, di mana nilai sig 0,049 lebih kecil dari dari nilai $\alpha=0,05$. Oleh sebab itu hipotesis yang diajukan ditolak artinya minat belajar berpengaruh signifikan terhadap hasil belajar Akuntansi siswa. Dimana hasil belajar siswa kelompok minat belajar tinggi lebih tinggi dibanding hasil belajar siswa yang memiliki minat belajar rendah. Hal ini berarti hasil belajar siswa yang memiliki minat belajar tinggi lebih baik dari pada siswa yang memiliki minat belajar rendah. Siswa dengan minat belajar tinggi pada kelas eksperimen memperoleh rata-rata hasil belajar 86,61 sedangkan siswa yang memiliki minat belajar rendah hanya memperoleh rata-rata hasil belajar 76,25. Disamping itu pada kelas kontrol siswa yang memiliki minat belajar tinggi memperoleh rata-rata hasil belajar 84,33 sedangkan siswa dengan minat belajar rendah hanya memperoleh rata-rata hasil belajar 73,12. 
Journal for Lesson and Learning Studies Vol. 1 No. 3, 2018

P-ISSN : 2615-6148, E-ISSN : 2615-7330

Dayang Weni Lisdarsih (2016) Berdasarkan data hasil belajar peserta didik setelah dilaksanakan penelitian, maka secara umum dapat disimpulakan bahwa terdapat pengaruh dari penggunaan model pair check Berbasis Penilaian Kinerja terhadap hasil belajar IImu Pengetahuan Sosial kelas IV Madrasah Ibtidaiyah Negeri Pontianak Tenggara. Hal ini dapat dilihat dari : (1) Dari hasil post-test kelas kontrol dan kelas eksperimen terdapat perbedaan hasil belajar IImu Pengetahuan Sosial dimana rata-rata hasil belajar kelas eksperimen yang diajar dengan menggunakan model pair check adalah sebesar 77,75 sedang hasil belajar kelas kontrol yang diajar tanpa menggunakan model pair check adalah sebesar 63,00. Berdasarkan hasil pengujian hipotesis (uji-t) menggunakan ttest polled varian diperoleh thitung $=6,54$ dan ttabel $=1,66732$ dengan taraf signifikan $\alpha=5 \%$ dan $\mathrm{dk}=77$, dengan demikian maka $\mathrm{Ha}$ diterima dan Ho ditolak. Hal ini berarti terdapat pengaruh model pair check terhadap hasil belajar IImu Pengetahuan Sosial kelas IV Madrasah Ibtidaiyah Negeri Pontianak. (2) Besarnya kontribusi dari penggunaan model pair check terhadap hasil belajar IImu Pengetahuan Sosial peserta didik kelas IV Madrasah Ibtidaiyah Negeri Pontianak Tenggara adalah sebesar 1,04. Yantiani Ni Made (2013) Adapun kesimpulan dari masalah yang telah dipaparkan adalah sebagai terdapat perbedaan yang signifikan hasil belajar siswa yang mengikuti model pembelajaran kooperatif tipe pair check Berbasis Penilaian Kinerja dengan siswa yang mengikuti pembelajaran konvensional. Ini diitunjukkan dengan hasil uji-t yang telah dilakukan yakni thitung $\geq$ ttabel, yaitu $9,11 \geq 2,021$ serta perolehan rerata yang berbeda yaitu 85,43 pada kelompok eksperimen dan 58,40 pada kelompok kontrol. Sehingga ini berarti terdapat pengaruh model pembelajaran kooperatif tipe pair check Berbasis Penilaian Kinerja terhadap hasil belajar materi bangun ruang dan bangun datar siswa pada siswa kelas IV Sekolah Dasar Gugus IV Semarapura tahun Ajaran 2012/2013. Mita Puspita (2014) Adapun kesimpulan yang dapatdisampaikan setelah melaksanakan danmemperoleh hasil dari penelitian sebagai berikut. Dari hasil perhitungan rata-rata kelompok eksperimen $=79,05$ dan kelompok kontrol diperoleh rata-rata $=73,03$. Dari perhitungan uji-t, diperoleh thitung $=7,25$ dan ttabel $=2,000$. Kedua hasil analisis tersebut dibandingkan maka diperoleh thitung $>$ ttabel $(7,25>2,000)$. Dari perbandingan ini maka hipotesis nol ditolak hipotesis alternatif diterima, yang artinya terdapat perbedaan yang signifikan hasil belajar IPA antara siswa yang mengikuti pembelajaran berbasis penilaian kinerja dengan siswa yang mengikuti pembelajaran konvensional pada siswa kelas V SDN Gugus 7 Kecamatan Penebel Kabupaten Tabanan Tahun Ajaran 2013/2014. Hal ini berarti dalam penelitian ini menunjukkan terdapat pengaruh penerapan pembelajaran berbasis penilaian kinerja terhadap hasil belajar IPA siswa kelas V SDN Gugus 7 Kecamatan Penebel Kabupaten Tabanan Tahun Ajaran 2013/2014.

\section{Metode}

Penelitian yang dilakukan ini merupakan penelitian eksperimen. Mengingat tidak semua variabel (gejala yang muncul) dan kondisi eksperimen dapat diatur dan dikontrol secara ketat, maka penelitian ini dikategorikan penelitian eksperimen semu (quasi experiment). Penelitian ini dilaksanakan pada siswa kelas V SD gugus Ir. Soekarno Kecamatan Denpasar Selatan. Rancangan penelitian yang digunakan dalam penelitian ini adalah Nonequivalent Control Group Design. Untuk rancangan analisis uji hipotesis dalam penelitian ini, menggunakan rancangan dua faktor versi factorial $2 \times 2$ dengan memperhatikan variabel-variabel yang ada.

Populasi penelitian ini adalah seluruh siswa SD gugus Ir. Soekarno Kecamatan Denpasar Selatan yang terdiri dari 392 orang. Pengambilan sampel pada penelitian ini dilakukan dengan teknik random sampling, yang dirandom adalah kelas V yang terdapat di SD gugus Ir. Soekarno Kecamatan Denpasar Selatan. Pengambilan sampel dengan menggunakan random sampling 
Journal for Lesson and Learning Studies Vol. 1 No. 3, 2018

P-ISSN : 2615-6148, E-ISSN : 2615-7330

dengan cara undian dengan jumlah siswa 79 siswa yang terdiri dari dua sekolah yaitu kelas $\mathrm{V}$ SD Negeri 10 Pedungan sebagai kelas ekperimen dan kelas VB SD Negeri 14 Pedungan sebagai kelas control. Penelitian ini melibatkan variabel bebas, variabel terikat dan variabel moderator. variabel bebas adalah variabel yang mempengaruhi atau yang menjadi sebab perubahannya atau timbulnya variabel dependen (terikat).

Variabel bebas dalam penelitian ini adalah pendekatan saintifik berbasis penilaian kinerja. Menurut Sugiyono (2014:61) variabel terikat merupakan variabel yang dipengaruhi atau menjadi akibat, karena adanya variabel bebas, dalam penelitian ini variabel terikatnya adalah Penguasaan kompetensi kognitif IPS Kelas V. Sedangkan variabel moderator adalah variabel yang mempengaruhi (memperkuat dan memperlemah) hubungan antara variabel independen dengan dependen (Sugiyono, 2012:62) Dalam penelitian ini, sebagai variabel moderator adalah berpikir kreatif tinggidan berpikir kreatif rendah.

Pengumpulan data dalam penelitian ini adalah data hasil pembelajaran pengetahuan IPS siswa kelas V ditinjau dari berpikir kreatif siswa SD gugus Ir. Soekarno Kecamatan Denpasar Selatan. Data yang diperlukan dalam penelitian ini dikumpulkan dengan metode tes dan tepikir kreatif berupa tes esay. Instrumen yang digunakan untuk mengumpulkan data kompetensi pengetahuan IPS adalah tes hasil belajar subjektif dalam bentuk esay dengan jumlah pertanyaan yakni10 butir soal. Untuk penskoran yaitu kisaran skor dari 0 - 2 skor menjawab benar pada setiap item butir soal. Jadi skor setiap jawaban dijumlahkan dan jumlah tersebut menjadi skor variabel hasil belajar IPS yang bergerak dari kisaran 0 - 100. 0 merupakan skor minimal ideal dan 100 merupakan skor maksimal tes hasil belajar IPS. Sebanyak 10 butir soal yang diberikan kepada siswa kelas $\mathrm{V}$ memiliki tujuan validasi butir tes. Hasil validasi akan diberikan kepada siswa kelompok eksperimen dan kelompok kontrol untuk mengetahui kemampuan kompetensi kognitif IPS.

Kompetensi yang digunakan dalam penelitian ini merupakan penggabungan dari aspek esay dan afektif. Dalam hal ini aspek afektif yaitu berpikir kreatif tinggi siswa dikumpulkan melalui metode tes esay. Tes berpikir kreatif ini menggunakan kategori jawaban dari jawaban Skor instrumen dari (1) sampai (2).Uji coba instrument pada penelitian ini dilakukan pada tes penguasaan kompetensi pengetahuan IPS dan tes berpikir kreatif secara empirik tentang layak atau tidaknya instrumen tersebut digunakan sebagai instrumen penelitian. Uji coba instrumen dilakukan dengan menentukan validitas item, daya pembeda, tingkat kesukaran dan reliabilitas. Pengujian validitas isi dapat dibantu dengan menggunakan kisi - kisi instrumen. Untuk menguji validitas isi dapat digunakan pendapat dari ahli (judgment experts) dengan mengkonsultasikan instrumen dengan para ahli yang dalam hal ini dosen mata kuliah IPS.

Data pada penelitian ini dianalisis menggunakan dua cara yaitu analisis deskriptif dan uji hipotesis. Analisis deskriptif digunakan untuk mendeskripsikan data penguasaan kompetensi pengetahuan IPS siswa. Untuk uji hipotesis penelitian dianalisis menggunakan teknik analisis statistik parametrik yaitu Analisis Varian (ANAVA) dua jalur. Sebelum uji hipotesis dilakukan uji prasyarat karena ANAVA dua jalur merupakan salah satu bentuk analisis statistik parametrik., yaitu uji prasyarat yang dilakukan terdiri dari Uji Normalitas Sebaran Data dan Uji Homogenitas Varian. Setelah uji ANAVA dua jalur, dilanjutkan dengan uji lanjut (post hoc) atau perbandingan berganda (multiple comparisons). Uji lanjut ini diperlukan karena analisis varian hanya mampu mengungkapkan ada atau tidaknya perbedaan dari tiga atau lebih kelompok data. Analisis varian tidak dapat menentukan rata-rata antar sel yang sebenarnya yang berbeda secara signifikan. Uji lanjut yang digunakan adalah uji Scheffe (karena $\mathrm{n}$ tidak sama). 
Journal for Lesson and Learning Studies Vol. 1 No. 3, 2018

P-ISSN : 2615-6148, E-ISSN : 2615-7330

\section{Hasil dan Pembahasan}

Berdasarkan hasil deskripsi data diperoleh hasil : (1) Kelompok siswa yang dibelajarkan melalui pendekatan saintifik berbasis penilaian kinerja, nilai rata-rata hitung (mean) $=74,3$, modus $=59,02$, median $=74,14$ dan simpangan baku $(S D)=13,98$. (2) Kelompok siswa yang dibelajarkan melalui pendekatan saintifik, nilai rata-rata hitung (mean) $=67,73$, modus $=774,5$, median $=69$ dan simpangan baku $(S D)=12,09$. (3) Kelompok siswa yang memiliki kemampuan berpikir kreatif tinggi, nilai rata-rata hitung (mean) $=70,7$, modus $=58,7$, median $=73,02$ dan simpangan baku (SD) $=13,82$. (4) Kelompok siswa yang memiliki kemampuan berpikir kreatif Rendah, nilai rata-rata hitung (mean) $=69,20$, modus $=62,5$ dan median $=65,5$ dan simpangan baku $(\mathrm{SD})=12,40$. (5) Kelompok siswa yang dibelajarkan melalui pendekatan saintifik berbasis penilaian kinerja dan memiliki kemampuan berpikir kreatif tinggi, Nilai rata-rata hitung (mean) $=74,28$, modus $=84,1$, median $=76$ dan simpangan baku $(S D)=15,66$. (6) Kelompok siswa yang dibelajarkan melalui pendekatan saintifik berbasis penilaian kinerja dan memiliki kemampuan berpikir kreatif rendah, nilai rata-rata hitung (mean) $=71,05$, modus $=58,79$, median $=70,37$ dan simpangan baku $(\mathrm{SD})=12,37$. (7) Kelompok siswa yang dibelajarkan melalui pendekatan saintifik dan memiliki kemampuan berpikir kreatif tinggi, Nilai rata-rata hitung (mean) $=67,46$, modus $=58,3$, median $=69,5$ dan simpangan baku $(S D)=11,64$. (8) pada Kelompok siswa yang dibelajarkan melalui pendekatan saintifik dan memiliki kemampuan berpikir kreatif rendah, Nilai rata-rata hitung (mean) $=65,4$ modus $=75,5$ median $=67,5$ dan simpangan baku $(\mathrm{SD})=12,90$.

Pada penelitian ini Uji normalitas menggunakan Chi-Kuadrat $\left(X^{2}\right)$ pada kedelapan kelompok data yaitu: (1) kelompok $A 1=$ data kelompok siswa yang dibelajarkan Melalui pendekatan saintifik berbasis penilaian kinerja; (2) kelompok A2 = data kelompok siswa yang melalui pendekatan saintifik; (3) kelompok B1 = data kelompok siswa yang memiliki kemampuan berpikir kreatif tinggi; (4) kelompok $\mathrm{B} 2=$ data kelompok siswa yang kemampuan berpikir kreatif rendah; (5) kelompok A1B1 = data kelompok siswa yang dibelajarkan melalui pendekatan saintifik berbasis penilaian kinerja dan memiliki kemampuan berpikir kreatif tinggi; (6) kelompok A2B1 =data kelompok siswa yang dibelajarkan pendekatan saintifik dan memiliki kemampuan berpikir kreatif tinggi; (7) kelompok A1B2 = data kelompok siswa yang dibelajarkan melalui pendekatan saintifik berbasis penilaian kinerja dan memiliki kemampuan berpikir kreatif rendah; dan (8) kelompok A2B2 = data kelompok siswa yang dibelajarkan melalui pendekatan saintifik dan memiliki kemampuan berpikir kreatif rendah. Berdasarkan kurva normal, kelas interval, frekuensi observasi $\left(f_{o}\right)$ dan frekuensi empirik $\left(f_{e}\right)$ data hasil belajar IPA siswa pada kedelapan kelompok tersebut diperoleh hasil analisis uji Chi-Kuadrat $\left(X^{2}\right)$ menunjukkan bahwa pada taraf signifikansi $5 \%(\alpha=0,05)$ dan $\mathrm{dk}=5$, diperoleh $\mathrm{X}^{2}{ }_{\text {hitung }}<\mathrm{X}^{2}$ tabel. Hal ini berarti $\mathrm{H}_{0}$ diterima, sehingga kedelapan kelompok data berdistribusi normal.Pada penelitian ini uji homogenitas untuk mengetahui homogenitas varian dari keempat kelompok sampel dengan menggunakan uji Bartlett (Test Bartlett). Keempat kelompok sampel yang diuji homogenitasnya yaitu kelompok A1B1, kelompok A2B1, kelompok A1B2 dan kelompok A2B2. Hasil analisis menggunakan Uji Bartlett, diperoleh nilai $X 2=2,05$ sedangkan nilai $X 2$ tabel pada taraf signifikansi $5 \%(\alpha=0,05 ; d k=3)=7,81$. $\mathrm{Hal}$ ini menunjukkan bahwa nilai X2 hitung $=2,05<\quad \mathrm{X} 2$ tabel=7,81. Hal ini berarti $\mathrm{H} 0$ diterima, sehingga varian keempat kelompok dinyatakan memiliki sebaran data yang homogen.

Berdasarkan hasil uji normalitas sebaran data dan homogenitas varian tersebut, dapat disimpulkan bahwa persyaratan untuk pengujian hipotesis dapat dipenuhi dan berdistribusi normal serta homogen Dengan demikian, pengujian hipotesis dengan menggunakan statistik parametrik yaitu analisis varian (ANAVA) dua jalur dapat dilanjutkan. 
Journal for Lesson and Learning Studies Vol. 1 No. 3, 2018

P-ISSN : 2615-6148, E-ISSN : 2615-7330

Tabel 1. Tabel Analisis Varians Dua Jalur

\begin{tabular}{cccccccc}
\hline SV & JK & Db & RJK & Fh & \multicolumn{2}{c}{ Ftabel } & Ket, \\
\cline { 6 - 7 } & & & & & $5 \%$ & $1 \%$ & \\
$\mathrm{JK}_{\mathrm{A}}$ & 773,63 & 1 & 773,63 & 4,94 & 3,98 & 7,01 & Signifikan \\
$\mathrm{JK}_{\mathrm{B}}$ & 180,6 & 1 & 180,6 & 0,97 & 3,98 & 7,01 & $\begin{array}{c}\text { Tidak } \\
\text { JK }\end{array}$ \\
$\mathrm{JK}_{\mathrm{AB}}$ & 1918,6 & 1 & 1918,6 & 12,28 & 3,98 & 7,01 & Signifikan \\
$\mathrm{JK}_{\text {dal }}$ & 11083,54 & 75 & & - & & & \\
Total & 13956,37 & - & - & - & & & \\
\hline
\end{tabular}

Terdapat perbedaan yang signifikan kompetensi pengetahuan IPS antara kelompok siswa yang dibelajarkan melalui pendekatan saintifik berbasis penilaian kierja dengan kelompok siswa yang dibelajarkan melalui pendekatan saintifik, Tidak terdapat perbedaan yang signifikan kompetensi pengetahuan IPS antara kelompok siswa yang memiliki kemampuan berpikir kreatif tinggi dengan kelompok siswa yang memiliki kepercayaan diri kemampuan berpikir kreatif. Terdapat interaksi yang signifikan antara pendekatan pembelajaran dengan berpikir kreatif terhadap kompetensi kognitif siswa.

Berdasarkan simpulan tersebut, $F_{A B}$ memiliki pengaruh interaksi signifikan maka dilanjutkan dengan uji lanjut untuk menentukan rerata antar sel. Uji lanjut yang digunakan adalah Uji Scheffe ( $\mathrm{n}$ tidak sama). Adapun kriteria pengujian yaitu, jika nilai $\mathrm{F}$ hitung lebih besar daripada F' (nilai F Scheffe) maka dikatakan terdapat perbedaan yang signifikan.

Tabel 2. Tabel Ringkasan Analisis Uji Lanjut Scheffe

\begin{tabular}{ccccc}
\hline No & $\begin{array}{c}\text { Rerata Kelompok yang } \\
\text { Diuji }\end{array}$ & $\mathrm{F}_{\text {hit }}$ & $\mathrm{F}^{\prime}$ & Keterangan \\
\hline 1. & $\mathrm{~A}_{1} \mathrm{~B}_{1}-\mathrm{A}_{1} \mathrm{~B}_{2}$ & 6,54 & 8,22 & Tidak Signifikan \\
2. & $\mathrm{~A}_{2} \mathrm{~B}_{1}-\mathrm{A}_{1} \mathrm{~B}_{2}$ & 6,49 & 8,22 & Tidak Signifikan \\
3. & $\mathrm{~A}_{1} \mathrm{~B}_{2}-\mathrm{A}_{2} \mathrm{~B}_{2}$ & 22,57 & 8,22 & Signifikan \\
4. & $\mathrm{~A}_{1} \mathrm{~B}_{1}-\mathrm{A}_{2} \mathrm{~B}_{2}$ & 50,67 & 8,22 & Signifikan \\
5. & $\mathrm{~A}_{1} \mathrm{~B}_{1}-\mathrm{A}_{2} \mathrm{~B}_{1}$ & 7,98 & 8,22 & Tidak Signifikan \\
6. & $\mathrm{~A}_{2} \mathrm{~B}_{1}-\mathrm{A}_{2} \mathrm{~B}_{2}$ & 6,96 & 8,22 & Tidak Signifikan \\
\hline
\end{tabular}

Berdasarkan hasil analisis data tabel diatas, dapat ditarik simpulan sebagai berikut. 1) Uji $F\left(A_{1} B_{1}-A_{1} B_{2}\right)_{\text {hitung }}=6,54>8,22$, sehingga hipotesis nol $\left(H_{0}\right)$ diterima. Hal ini berarti terdapat perbedaan yang signifikan hasil belajar IPS antara siswa yang memiliki kemampuan berpikir kreatif tinggi dengan siswa yang memiliki kemampuan berpikir kreatif rendah pada siswa yang dibelajarkan melalui pendekatan saintifik berbasis penilaian kinerja. 2) Uji $F\left(A_{2} B_{1}-A_{1} B_{2}\right)$ hitung $=$ $6,49>8,22$, sehingga hipotesis nol $\left(H_{0}\right)$ diterima. Hal ini berarti terdapat perbedaan yang signifikan hasil belajar IPS antara siswa yang dibelajarkan melalui pendekatan saintifik pada siswa yang memiliki kemampuan berpikir kreatif tinggi dengan kelompok siswa yang dibelajarkan melalui pendekatan saintifik berbasis penilaian kinerja pada siswa yang memiliki kemampuan berpikir kreatif rendah. 3) $\mathrm{Uji} F\left(A_{1} B_{2}-A_{2} B_{2}\right)$ hitung $=22,57<8,22$, sehingga hipotesis nol $\left(\mathrm{H}_{0}\right)$ ditolak. Hal ini berarti pada siswa yang memiliki kemampuan berpikir kreatif rendah terdapat perbedaan yang signifikan hasil belajar IPS antara kelompok siswa yang dibelajarkan melalui pendekatan saintifik berbasis penilaian kinerja dengan kelompok siswa yang 
Journal for Lesson and Learning Studies Vol. 1 No. 3, 2018

P-ISSN : 2615-6148, E-ISSN : 2615-7330

dibelajarkan melalui pendekatan saintifik konvensional. 4) Uji $F\left(A_{1} B_{1}-A_{2} B_{2}\right)_{\text {hitung }}=50,67>8,22$, sehingga hipotesis nol $\left(\mathrm{H}_{0}\right)$ ditolak. Hal ini berarti terdapat perbedaan yang signifikan hasil belajar IPS antara siswa yang dibelajarkan melalui pendekatan saintifik berbasis penilaian kinerja pada siswa yang memiliki kemampuan berpikir kreatif tinggi dengan kelompok siswa yang dibelajarkan melalui pendekatan saintifik pada siswa yang memiliki kemampuan berpikir kreatif rendah. 5) Uji $F\left(A_{1} B_{1}-A_{2} B_{1}\right)_{\text {hitung }}=7,98>8,22$, sehingga hipotesis nol $\left(H_{0}\right)$ diterima. Hal ini berarti pada siswa yang memiliki kemampuan berpikir kreatif tinggi terdapat perbedaan yang signifikan hasil belajar IPS antara kelompok siswa yang dibelajarkan melalui pendekatan saintifik berbasis penilaian kinerja dengan kelompok siswa yang dibelajarkan melalui pendekatan saintifik. 6) Uji $F\left(A_{2} B_{1}-A_{2} B_{2}\right)$ hitung $=6,96>8,22$, sehingga hipotesis nol $\left(H_{0}\right)$ ditolak. $\mathrm{Hal}$ ini berarti terdapat perbedaan yang signifikan hasil belajar IPS antara siswa yang memiliki kemampuan berpikir kreatif tinggi dengan siswa yang memiliki kemampuan berpikir kreatif rendah pada siswa yang dibelajarkan melalui pendekatan saintifik konvensional

Berdasarkan hasil uji hipotesis, maka hasil uji hipotesis Pertama, $F_{A}=4,47>F_{\text {tabel }(\alpha=0,05 \text {; }}$ ${ }_{1,82))}=3,98$, sehingga hipotesis nol $\left(\mathrm{H}_{0}\right)$ ditolak. Hal ini berarti secara keseluruhan terdapat perbedaan yang signifikan hasil belajar IPS antara kelompok siswa yang dibelajarkan melalui pendekatan saintifik dengan kelompok siswa yang dibelajarkan melalui pendekatan saintifik. Dengan kata lain, pendekatan saintifik berbasis penilaian kinerja berpengaruh terhadap hasil belajar IPS siswa kelas V SDN Gugus Ir.Soekarno Tahun Pelajaran 2015/2016. Kedua, Hipotesis kedua yang diuji ialah $F_{B}=0,97>F_{\text {tabel }(\alpha=0,05 ; 1,82))}=3,98$ sehingga hipotesis nol $\left(H_{0}\right)$ diterima. Hal ini berarti secara keseluruhan tidak terdapat perbedaan yang signifikan antara penguasaan kompetensi kognitif IPS dengan kemampuan berpikir kreatif tinggi dan kemampuan berpikir kreatif rendah siswa kelas V SDN Gugus Ir.Soekarno Denpasar Selatan Tahun Pelajaran 2015/2016. Hal yang menjadi penyebab utama adalah kondisi - kondisi lingkungan siswa yang tidak mendukung terhadap suasana terbuka terhadap gagasan baru yang dapat memupuk kreativitas siswa.

Ketiga, $F_{A B}=12,28>F_{\text {tabel }(\alpha=0,05 ; 1,82))}=3,98$ hipotesis nol $\left(H_{0}\right)$ ditolak. Hal ini berarti secara keseluruhan terdapat pengaruh interaksi Pendekatan saintifik berbasis penilaian kinerjadan berpikir kreatif terhadap hasil belajar IPS siswa kelas V SDN Gugus Ir.Soekarno Denpasar Selatan Tahun Pelajaran 2015/2016. Hal ini berarti interaksi model pembelajaran pendekatan saintifik berbasis peniliaian kinerja dengan kemampuan berpikir kreatif dapat memberikan pengaruh positif terhadap hasil belajar IPS siswa.

\section{Simpulan dan Saran}

Berdasarkan hasil pengujian hipotesis pada penelitian ini maka dapat disimpulkan bahwa: (1) Terdapat perbedaan yang signifikan hasil belajar IPS antara siswa yang dibelajarkan melalui pendekatan saintifik berbasis penilaian kinerja dengan kelompok siswa yang dibelajarkan melalui pendekatan saintifik konvensional pada siswa kelas V SDN Gugus Ir. Soekarno Denpasar Selatan; (2) Terdapat perbedaan yang signifikan kompetensi pengetahuan IPS antara siswa yang Hal ini berarti secara keseluruhan tidak terdapat perbedaan yang signifikan antara penguasaan kompetensi kognitif IPS dengan kemampuan berpikir kreatif tinggi dan kemampuan berpikir kreatif rendah siswa kelas V SDN Gugus Ir.Soekarno Denpasar Selatan; 3) Terdapat pengaruh interaksi antara pendekatan saintifik berbasis penilaian kinerja dan berpikir kreatif terhadap hasil belajar IPS pada siswa kelas V SDN Gugus Ir.Soekarno Denpasar Selatan.

Berdasarkan hasil penelitian yang telah disimpulkan, terdapat beberapa saran yang dikemukakan sebagai berikut. (1) Kepada siswa, Dari hasil penelitian ini maka disarankan untuk lebih meningkatkan kemampuan berpikir kreatif siswa sehingga dapat memperoleh hasil belajar yang lebih baik khususnya pada mata pelajaran IPS;(2) Kepada Guru, Pendekatan Saintifik 
Journal for Lesson and Learning Studies Vol. 1 No. 3, 2018

P-ISSN : 2615-6148, E-ISSN : 2615-7330

berbasis penilaian kinerja dapat digunakan sebagai alternatif dalam pemilihan pendekatan pembelajaran yang inovatif, yaitu pembelajaran yang dapat membantu siswa belajar bermakna dan lebih aktif melalui pembelajaran yang menyenangkan. Guru juga perlu meningkatkan perannya sebagai fasilitator; (3) Kepada Peneliti Lain, Dalam penelitian ini dugankan materi pelajaran yang terbatas pada materi sejarah kebudayaan Islam sehingga untuk mengetahui hasil yang berbeda pada pokok bahasan lainnya, maka disarankan bagi mahasiswa maupun peneliti lain untuk melakukan penelitian yang sejenis pada pokok bahasan lainnya.

\section{Daftar Rujukan}

Admiyetti, Syamwil. 2016. Pengaruh Model Kooperatif Tipe Pair Check Berbasis Penilaian Kinerja dan Minat Siswa Terhadap Hasil Belajar Dalam Mata Pelajaran Akuntansi Kelas X SMKN 1 Lubuk Basung. E-journal Pendidikan Akuntansui UNP. Volume 2 nomor 1.

BSNP. 2011. Panduan Penyusunan Kurikulum Tingkat Satuan Pendidikan Dasar dan Menengah. Jakarta: BSNP.

Dayang Weni Lisdarsih. 2016. Pengaruh Model Pair Check Berbasis Penilaian Kinerja Terhadap Hasil Belajar IImu Pengetahuan Sosial Kelas IV. Jurnal Pendidikan dan Pengajaran UNTAN. Volume 5 Nomor 11.

Edy Setiyo Utomo. 2016. Pengaruh Model Pembelajaran Kooperatif Tipe Pair Check Berbasis Penilaian Kinerja Terhadap Hasil Belajar Siswa. Jurnal Pendidikan Matematika STKIP PGRI Jombang. Volume 1 Nomor 1.

Gunawan, Rudy. 2011. Pendidikan IPS Filosofi, Konsep, dan Aplikasi. Bandung: Alfabeta.

Hawadi, Reni Akbar dkk. 2010. Kreativitas. Jakarta : Pt Grasindo

Mita Puspita. 2014. Pengaruh Penerapan Pembelajaran Berbasis Penilaian Kinerja terhadap Hasil Belajar IPA Siswa Kelas V pada Gugus 7 Kecamatan Penebel Kabupaten Tabanan. Jurnal Mimbar PGSD Undiksha. Volume 2 nomor 1.

Putri Ayu Widiadnyani. 2014. Pengaruh Model Pembelajaran Pair Cheks Berbasis Penilaian Kinerja berbantuan Media Lingkungan Hidup terhadap Hasil Belajar IPA Kelas V SDN 5 Pedungan Tahun Ajaran 2013/2014. Jurnal Mimbar PGSD Undiksha. Volume 2 Nomor 1.

Susanto, Ahmad. 2014. Teori Belajar dan Pembelajaran.Jakarta : Kencana Prenamadia Group

Sugiyono, 2012. Metode Penelitian Pendidikan (Pendekatan Kuantitatif, Kualitatif dan R\&D). Bandung: Alfabeta.

Sugiyono. 2013. Metode Penelitian Administrasi Dilengkapi Dengan Metode R\&D. Bandung: Alfabeta

Suwarni hasibuan, hera deswita. 2017. Pengaruh Model Pembelajaran Pair Check Berbasis Penilaian Kinerja terhadap Hasil Belajar Matematika Siswa Kelas VIII SMP Negeri 2 Tambusai Kabupaten Rokan Hulu. Jurnal Pendidikan Matematika Universitas Pasir Pengaraian. Volume 3 Nomor 1. 
Journal for Lesson and Learning Studies Vol. 1 No. 3, 2018

P-ISSN : 2615-6148, E-ISSN : 2615-7330

Syah, Muhibbin. 2011. Psikologi Pendidikan. Bandung : Pt Remaja Rosdakarya 2014. Metode Penelitian Pendidikan (Pendekatan Kuantitatif, Kualitatif dan R\&D). Bandung: Alfabeta.

Widiadnyani, Luh Gd. Putri Ayu. 2014. "Pengaruh Model Pembelajaran Pair Check Berbasis Penilaian Kinerja Berbatuan Media Lingkungan Hidup Terhadap Hasil Belajar IPA Kelas V SDN 5 Pedungan Tahun Ajaran 2013/2014". E-JournalPGSD Undiksha Mimbar PGSD Volume 2, No.1 (hlm. 1-10) (diakses pada 17 Januari 2018).

Yantiani, Ni Md. 2013. "Pembelajaran Kooperatif Pair Check Berbasis Penilaian Kinerja Berpengaruh Terhadap Hasil Belajar Materi Bangun Ruang dan Bangun Datar Siswa Kelas IV Gugus IV Semarapura". E-Journal PGSD Undiksha Mimbar PGSD Volume 2, No.1 (hlm. 1-10) (diakses pada 17 Januari 2018). 